\title{
The barriers to low-carbon land-transport and policies to overcome them
}

\author{
Oliver Lah
}

Received: 23 November 2012 / Accepted: 10 November 2014 / Published online: 31 January 2015

(C) The Author(s) 2015. This article is published with open access at SpringerLink.com

\begin{abstract}
Considerable efficiency gains can be made costeffectively to set the transport sector on a sustainable development pathway. They can be achieved through already available technologies and practices, which will not only reduce greenhouse gas emissions significantly, but also generate social, environmental and economic co-benefits. However, progress in the take-up of low-carbon mobility measures substantially lags behind the potential. A number of barriers contribute to this lack of uptake. This paper explores those barriers by focusing on vehicle fuel efficiency in particular, but will also touch on the wider policy framework to improve the efficiency of the transport sector and reduce emissions. The paper suggests that a combination of fuel pricing, differentiated vehicle taxation, vehicle standards and the provision of modal choice are necessary to minimise rebound effects and significantly curb transport sector greenhouse gas emissions at low- or even negative cost.
\end{abstract}

Keywords Sustainability · Fuel efficiency $\cdot$ Policies · Low-carbon transport $\cdot$ Climate change

\section{Introduction}

The transport sector is a vital part of global climate change mitigation strategies, as it accounts for $23 \%$ of the energy related greenhouse gas emissions [36]. All available mitigation options are required to bring the transport sector on a $2^{\circ}$ Celsius stabilisation pathway [71]. This includes vehicle fuel efficiency, modal choice and compact urban design among

\section{O. Lah $(\bowtie)$}

Wuppertal Institute for Climate and Energy, WuppertalNeue Promenade 6, 10178, Berlin, Germany

e-mail: oliver.lah@wupperinst.org others, covering all transport modes and require the involvement of national as well as local levels of government.

There is a wealth of experience with local and national sustainable transport policy measures [33, 63]. However, beyond the design and implementation of single policies, a combination of measures is vital for their success in avoiding rebound effects and to foster the contribution of low-carbon mobility to sustainable development. This requires a mutually enforcing set of policy and infrastructure measures at the national and local level. This paper will highlight the key barriers for energy efficiency in the transport sector and outline the key elements of a policy package to overcome those barriers.

\section{Barriers to low-carbon transport}

Shifting to a low-carbon development pathway requires substantial efforts for the transport sector. One could argue, however, that fuel economy improvements are no-regret options to lower $\mathrm{CO}_{2}$ and harmful emissions, improve energy security and increase economic productivity [25]. There is an immediate need to improve vehicle fuel efficiency from an economic, societal and environmental perspective. Doing so harbours considerable potential for co-benefits if the efficiency technology is advanced enough to be introduced cost-effectively $[47,89]$. Vehicle fuel efficiency technologies are, however, substantially underutilised; while some countries have made noticeable progress in this area, others have largely failed to do so [36]. There are split incentives between societal and individual benefits that create a collective action problem, which inhibits optimal outcomes in this area. The following section will explore those barriers and emphasise the need for policy intervention. 


\subsection{Split incentives}

The initial-cost barrier is a major problem, in particular for individuals and despite available information on the relevant payback periods [21, 48]. The key factor inhibiting improvement of the vehicle fleet's efficiency is the split incentive between individual-cost and economy-wide benefits, which is very strong in the transport sector. Vehicle purchases are made by individuals who apply discount rates as high as $20 \%$, while most car buyers do not account for cost-savings from fuel efficiency beyond 2-3 years [38]. As such, only a fraction of the economy-wide benefits are considered by individuals when making a purchase decisions, with negative consequences on the economy-wide benefits/costs over the roughly 15 year lifetime of the vehicle.

The investment barrier is still the most prevalent obstacle to the widespread market penetration of energy efficient products [76]. A number of studies show that GHG reduction measures in transport have quite favourable abatement costs but require higher capital intensity than many measures in other sectors $[52,67]$. While these investments result in considerable economy-wide benefits over the lifetime of a vehicle, they may not create sufficient payback rates for the particular individuals responsible for vehicle purchasing decisions. Rebound effects may, however, undermine some of the efficiency gains, further complicating the collective action problem. These are examined in the following section.

\subsection{Rebound effects}

An additional issue affecting energy efficiency measures is the rebound or take-back effect. The effect refers to the tendency for total demand for energy decrease less than expected after energy efficiency improvements are introduced, due to the resultant decrease in the cost of energy services [22, 77]. Ignoring or underestimating this effect whilst planning policies may lead to inaccurate forecasts and unrealistic expectations of the outcomes, which, in turn, lead to significant errors in the calculations of policies' payback periods [92]. One of the most typical examples in the transport sector is improved vehicle efficiency failing to lead to the desired reduction in energy consumption, as efficiency gains are 'taken back' by increased travel.

Some authors even suggest that energy efficiency improvements can result in an increase of energy consumption: the rebound effect is larger than the original efficiency gain $[8,37,44]$. This claim has yet to be proven, but a number of studies show that the rebound effect is indeed an issue which should be addressed when developing effective energy efficiency policies [76], but should not serve as an excuse for not implementing efficiency policies [22]. The expected rebound effect is around 0-12\% for household appliances such as fridges and washing machines and lighting, while it is up to $20 \%$ in industrial processes and $10-30 \%$ for road transport [32]. The higher the potential rebound effect and also the wider the range of possible take-back, the greater the uncertainty of a policy's cost effectiveness and its effect upon energy efficiency [61].

\subsection{The collective action problem}

Personal motivation and political will to achieve collective action are aligned in many ways [57]. Individuals tend to be driven by rational behaviour and therefore favour the most cost effective choice, even though it may be morally objectionable [13]. In the case of global climate change, individual perpetrators can be relatively certain of getting away with bad behaviour (e.g. driving a large instead of a small car) if there is no policy framework influencing individual behaviour. This represents the typical social dilemma situation, which discourages individuals from cooperating, as they can free-ride on the contributions of others. Atmospheric pollution is a reverse tragedy-of-thecommons. It is not the situation of removing something from the commons but putting something into it (the atmosphere), namely carbon dioxide. The overuse of the atmosphere as dumping ground for greenhouse gases is the result of individuals making the rational decision to maximise their gain (wealth, comfort, status etc.) by increasing their carbon footprint or at least by not to reducing it [80]. This encourages bad behaviour, as good behaviour would be punished (e.g. higher travel time by taking the bus, or higher prices through flight emissions offsetting). Energy consumers are generally rational, however each individual acts differently. Governing the commons means also coping with the different habits of its users $[14,81]$.

\section{Co-benefits as cornerstone to overcome barriers and link policy objectives}

While from a climate change mitigation perspective vehicle efficiency and low-carbon fuels may provide the biggest potential, this does not fully reflect a broader sustainable transport perspective. A multimodal and integrated policy approach can minimise rebound effects, overcome splitincentives and achieve a higher level of socio-economic cobenefits [23]. Energy efficiency and low-carbon fuels have a key role to play in decarbonizing the transport sector. However, the strategies, in particular avoiding travel through compact city design and shifting to low-carbon modes (Avoid, Shift) are the measures that yield substantial opportunities to contribute to sustainable development (Table 1). 
Table 1 Greenhouse gas mitigation potential and co-benefits potential

\begin{tabular}{|c|c|c|c|}
\hline Approach & Area of focus & Potential impact & Potential synergies \\
\hline Avoid & $\begin{array}{l}\text { Activity (reduction and management: } \\
\text { short distances, compact cities and } \\
\text { mixed use) }\end{array}$ & $\begin{array}{l}\text { Potential to reduce energy consumtion by } 10 \text { to } \\
30 \%[50,82]\end{array}$ & $\begin{array}{l}\text { Reduced travel times; improved air quality; } \\
\text { public health; safety and more equitable } \\
\text { access }\end{array}$ \\
\hline Shiftt & $\begin{array}{l}\text { Structure (Shift to more energy efficient } \\
\text { modes) }\end{array}$ & $\begin{array}{l}\text { Potential for energy efficiency gains varies } \\
\text { greatly, } 10-30 \% \text { reductions }[19,35]\end{array}$ & $\begin{array}{l}\text { Reduce urban congestion and more equitable } \\
\text { access Freight.reduced maintenance costs for } \\
\text { road }\end{array}$ \\
\hline \multirow[t]{2}{*}{ Improve } & Intensity (vehicle fuel efficiency) & $\begin{array}{l}\text { Efficiency improvement of } 40-60 \% \text { by } 2030 \\
\text { feasible at low or negative cost }[20,35]\end{array}$ & $\begin{array}{l}\text { Improved energy security, productivity and } \\
\text { affordability }\end{array}$ \\
\hline & $\begin{array}{l}\text { Fuel (swith to electricity, hydrogen, } \\
\text { CNG, biofuels and other fuels) }\end{array}$ & $\begin{array}{l}\text { Changing the structure of the energy } \\
\text { consumption. Mitigation and efficiency } \\
\text { potential uncertain. }\end{array}$ & $\begin{array}{l}\text { Diversification of the fuels used contributes to } \\
\text { climate, air quality and / or energy security } \\
\text { objectives }\end{array}$ \\
\hline
\end{tabular}

Adapted from $[18,71]$

Air quality, safety, energy efficiency, access to mobility services and other factors that are considered to be co-benefits of sustainable transport measures from a climate change perspective are in fact the driving factors for policy intervention, in particular on the local level $[24,29,39,60]$. As transport relies almost entirely on petroleum products, energy security is a major issue for the sector products $[10,78]$. There is a direct link between energy security and climate change mitigation actions that focus on fuel switch options, such as biofuels and electrification [40, 46, 66] and demand side measures, such fuel efficiency, shift to more efficient transport modes and compact urban design [10, 49 79]. These strategies are also likely to improve access to mobility services and reduce transport costs, which affects positively productivity and social inclusion [6, 54] and provides better access to jobs, markets and social services $[4,7,70]$. Improved access is likely to have a positive impact on employment. A major cost factor generated by inefficient transport systems is congestion. Time lost in traffic was valued at $1.2 \%$ of GDP in the UK [24]; $3.4 \%$ in Dakar, Senegal; $4 \%$ in Manila, Philippines [9]; 3.3 to $5.3 \%$ in Beijing, China [12]; 1 to $6 \%$ in Bangkok, Thailand [91] and up to $10 \%$ in Lima, Peru with daily travel times of almost $4 \mathrm{~h}[41,45]$.

The combination of various policy objectives that can be addressed by an integrated multi-level policy and governance approach provides a solid basis for durable polcies that can have long-lasting impacts. Climate change, air quality, noise prevention, safety, energy security and productivity are key policy objectives for policy makers at the local and national level, even though to varying degrees $[40,59,84]$. The polices described in the following section provide a framework in which synergies between thee policy objectives can be generated to foster the contribution of low-carbon mobility to sustainable development.

\section{Policies to overcome the barriers to transport energy efficiency}

There are manifold policy options to increase the efficiency of the transport sector $[27,36,38,71]$. However, the ability of policy measures to generate co-benefits between several policy objectives to foster sustainable development and not just to one (e.g. energy efficiency or air quality) varies greatly. The following section outlines some of the main policies that are considered in this paper to be vital for a shift towards a pathway that contributes to sustainable development and is in line with the transport sector's contribution to a stabilization of 2 Degrees above pre-industrial levels [71]. This paper argues that vehicle efficiency standards, fuel taxes, differentiated vehicle taxes along with the provision of modal choices and compact city design are vital to reduce transport activity, shift towards a more efficient transport structure, improve the energy intensity of fuels and foster the uptake of low-carbon fuels. Only this integrated approach can generate the co-benefits needed to create coalitions among national and local stakeholders, which is necessary to overcome the barriers described before.

\subsection{National level policies}

\subsubsection{Vehicle fuel efficiency standards}

Fuel efficiency standards aim to ensure a supply of efficient vehicles and, even more importantly, aim to limit the level of fuel consumption throughout the vehicle fleet. For policymakers, the key benefit of this measure compared with other mechanisms is the need to deal with only a relatively small number of car manufacturers, whereas other policies usually target a vast number of individuals.

The provision of long-term efficiency targets offers certainty to vehicle manufacturers; crucial to them in order to make investments in new technologies [64]. To ensure equal conditions for all manufacturers, standards should apply to all 
vehicles entering the fleet, whether locally produced or imported. Moreover, efficiency targets should be combined with demand-side polices in order to ensure the supply of more efficient vehicles matches consumer demand. Together, the resultant changes have the potential to deliver the largest share of $\mathrm{CO}_{2}$ mitigation in the transport sector (Fig. 1).

However, there is also a debate about whether fuel economy standards alone are the most effective way of reducing transport fuel consumption and GHG emissions. While the major manufacturing countries have standards in place, they have failed to create substantive progress in lowering overall transport sector energy consumption. This is consistent with the observation that only integrated policy packages, including standards and fiscal measures, will achieve substantial results.

One of the key shortfalls of standards as the sole policy measure to reduce fuel consumption is related to the rebound effects they can initiate $[33,63,72,88]$. Vehicle efficiency standards reduce the cost of driving and hence promote increased travel [58]. However, increased travel associated with more stringent standards is not considered a strong argument against them, because the increased travel decreases as income grows [73]. Furthermore, the rebound effect can be minimised by appropriate fuel pricing, as discussed below. From a societal perspective, individuals do not act responsibly when making purchasing decisions. Consumers rarely evaluate the trade-off between higher initial cost for efficient vehicles and the benefit of fuel saved as previously mentioned. The gap between private and societal discount rates can be mitigated to some extent by policies, such as vehicle tax and vehicle standards.

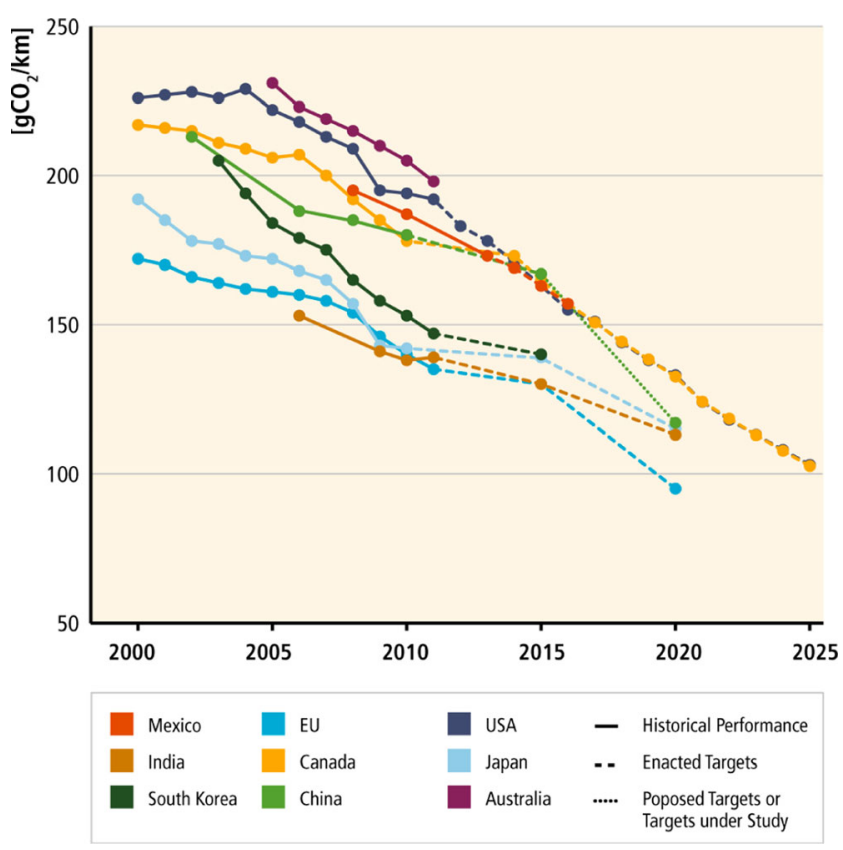

Fig. 1 Historic emissions and projected future carbon dioxide emissions targets for cars in selected countries [71], based on [31]
The USA was the first country to introduce vehicle fuel economy standards, in 1975, just 2 years after the first oil crisis, in form of the US CAFE standard. This requires car manufacturers to meet sales-weighted average fuel economy standards for light vehicles sold domestically. This mandatory standard was effective in improving fuel vehicle fuel efficiency for around a decade, with fleet-average fuel economy of passenger cars rising from approximately 15 miles per gallon $(15.68 \mathrm{~L} / 100 \mathrm{~km})$ in 1975 to approximately $28 \mathrm{mpg}$ by $1989(8.4 \mathrm{~L} / 100 \mathrm{~km})$. After oil prices recovered in the 1980s and policy-makers' attention in this area decreased, so did the effectiveness of the CAFE standards [65]. A number of factors contributed to this, most notably that CAFE standards remained unchanged for more than two decades and failed to include light trucks (SUVs) [27].

In an analysis of the policy which aimed to advance the attainment of the 2020 target $(35 \mathrm{mpg}$ ) to 2016, the US Environmental Protection Agency (EPA) came to the conclusion that the average price increase for model year 2015 cars and light trucks would be paid back from reduced fuel costs in 56 and 50 months, respectively (assuming manufacturers pass on costs to consumers, and fuel prices of US\$2.26 in 2016 and $\$ 2.51$ in 2030). Economy-wide net benefits (using a $7 \%$ discount rate) from lower fuel costs, reduced oil dependence and avoided external costs are estimated by NHTSA to be US $\$ 15.2 \mathrm{~b}$ for cars and $\$ 26.4 \mathrm{~b}$ for light trucks [55].

The EU has moved from voluntary arrangements with the automobile industry to regulation. The Regulation EC 443/2009 is based on a target of $130 \mathrm{~g} \mathrm{CO}_{2} / \mathrm{km}$ for the European car industry by 2015. The regulation also includes another target of $95 \mathrm{~g} / \mathrm{km}$ of $\mathrm{CO}_{2}$ by 2021 . While there is evidence suggesting that vehicle efficiency standards improve average vehicle efficiency over the medium to long-term [54], this measure appears to deliver only modest system-wide efficiency improvements. For example, the EU voluntary agreement improved average light vehicle fleet fuel economy, using to the standard European test cycle (NEDC), by about $10 \%$ between 1996 and 2008 [17]. However, in the same period, total passenger car $\mathrm{CO}_{2}$ emissions fell by only $\approx 4 \%$ (ibd.), indicating a substantial rebound effect. Hence technology improvement focused measures require policies that can influence consumer behaviour (differentiated vehicle taxes) and can manage vehicles use (fuel tax). In addition, super credits, manufacturer pools and credits for ecoinnovation and tolerances and flexibilities of the European test cycle (NEDC) can further weaken the effectiveness of the envisaged targets. Hence, managing fuel use through fuel taxation and providing modal choices is vital, not only for the efficiency of the transport system, but also for its ability to contribute to sustainable (urban) development [2].

\subsection{Fuel taxes}

Fuel taxes and excise duty rates should be set at a level, which internalises external costs (e.g. from GHG emissions) [5, 51]. 
Doing so directly affects travel demand, modal choice and vehicle technology choices [11]. Also, fuel prices can have a significant impact on vehicle ownership rates. The impact of fuel price changes on consumption is defined as its price-elasticity. In the short-term, there is little change in demand in response to price changes [92], e.g. a $10 \%$ fuel-price increase results in only $0.11-0.6 \%$ lower demand $[24,56]$, i.e. fuel demand is inelastic in the short term. However, more sustained fuel price increases, e.g. from taxation, result in considerable energy demand reductions: a $10 \%$ fuel price increase will result in a 2.5 to $3 \%$ energy use decrease in the first year and up to $6 \%$ after 5 years [24].

Fuel prices not only affect energy demand, but also vehicle choice. A $10 \%$ petrol price increase would lead to a fleetaverage $\mathrm{CO}_{2}$ emissions reduction of $\approx 0.5 \mathrm{~g} / \mathrm{km}$ ithe first year, and up to $\approx 2.8 \mathrm{~g} / \mathrm{km}$ in the longer term [62]. Goodwin [24] estimate the vehicle efficiency improvement generated by a $10 \%$ fuel price increase to be $11 \%$ over the long-term. Despite this evidence, there are remarkable differences in fuel taxation across OECD countries (Fig. 2).

\subsection{Differentiated vehicle taxation}

Differentiated vehicle registration, purchase taxes and/or feebate schemes can guide consumer demand and help mitigate split incentives between individuals and society. Figure 3 provides an overview on a selection of countries and their approach to differentiation in circulation tax.

These schemes have to respond to changes in the vehicle fleet to ensure sufficient demand for more efficient vehicles and to maximise cost-effectiveness $[83,56]$. Circulation/ ownership taxes are a recurring charge (typically yearly), which can be used to encourage purchasing more efficient cars by setting the charge according to cars' fuel economy, either directly or by proxy $\left(\mathrm{CO}_{2}\right.$ emissions, engine size or power-to-weight ratio). Linking taxes to greenhouse gas and harmful emissions in this way is a well established and studied policy measure, and has proven to be more cost-effective than enforcing direct controls [6].

Ryan et al. [62] analyse fiscal instruments' influence on individual purchasing decisions, finding that vehicle and fuel taxes have a considerable influence on the efficiency of vehicles entering the fleet. A $10 \%$ increase in vehicle circulation taxes could result in a short-term fleet $\mathrm{CO}_{2}$ emissions decrease of $0.3 \mathrm{~g} / \mathrm{km}$, increasing to $1.4 \mathrm{~g} / \mathrm{km}$ in the long term [62]. The European Commission considers it essential to differentiate taxes, rewarding energy efficient cars with significantly lower taxes and imposing considerable taxes on cars with poor fuel efficiency. .) found that replacing existing vehicle taxes with taxes dependant on only $\mathrm{CO}_{2}$ emissions, with sufficient differentiation, led to the largest reductions. Where differentiated taxes already exist, adding a $\mathrm{CO}_{2}$ emissions dependant element provides smaller, but still significant reductions. For example, the Irish $\mathrm{CO}_{2}$ emissions-differentiated vehicle tax is estimated to have resulted in a 3.6-3.8 \% emissions intensity reduction and an annual reduction of transport $\mathrm{CO}_{2}$ emissions of $3 \%$ [21]. Under a feebate system, the rate of progression is being increased over time, and thus lead to even greater $\mathrm{CO}_{2}$ emissions reduction, but significant savings also could be achieved by increasing the differentiation of existing taxes.

\subsubsection{Registration taxes}

By imposing higher taxes on the purchase of less efficient vehicles, registration taxes influence consumer behaviour directly at the point of vehicle sale. Denmark's purchase-tax system led to an average fuel efficiency increase of $4.1 \mathrm{l} /$ $100 \mathrm{~km}$ for diesel light vehicles and $0.6 \mathrm{l} / 100 \mathrm{~km}$ for petrol
Fig. 2 Taxes on unleaded petrol in OECD countries from 1998 to 2009 (OECD Tax Database 2013)

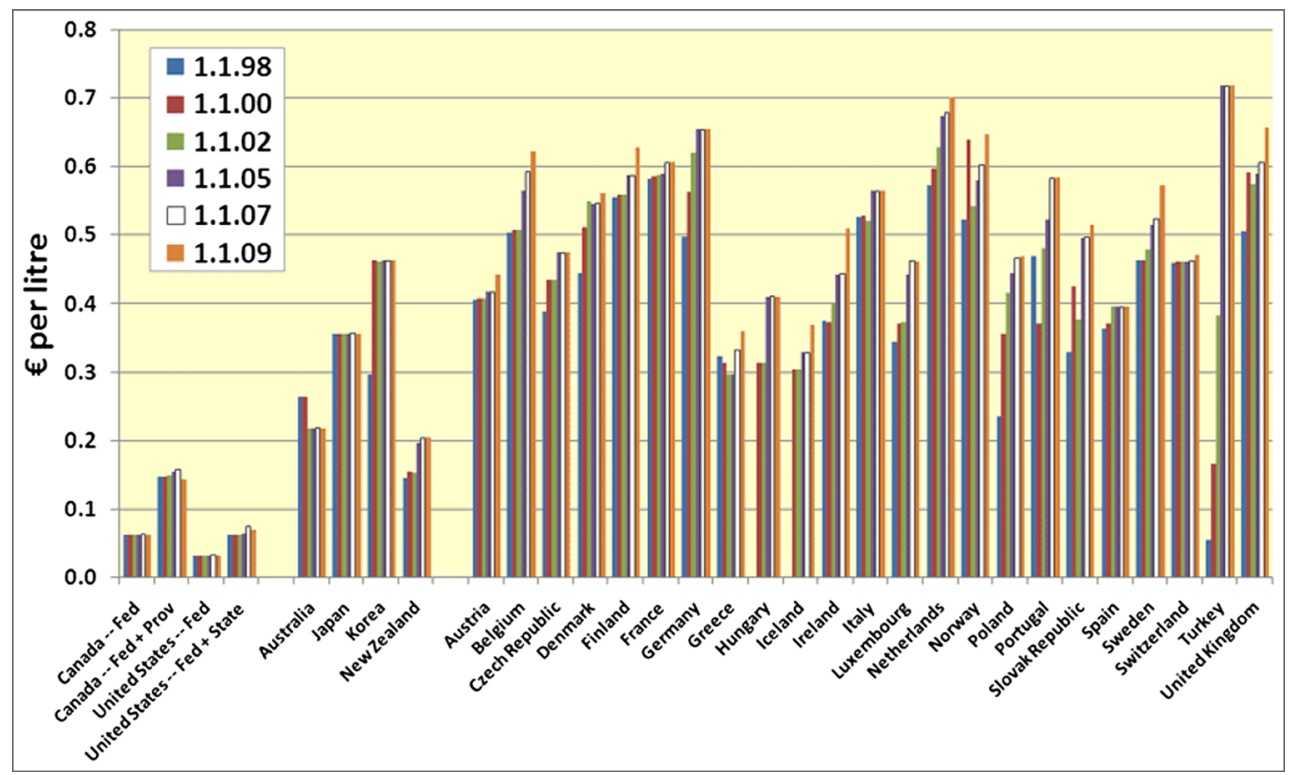


Fig. 3 Differentiated circulation vehicle taxation in selected European countries (OECD Tax Database 2013)

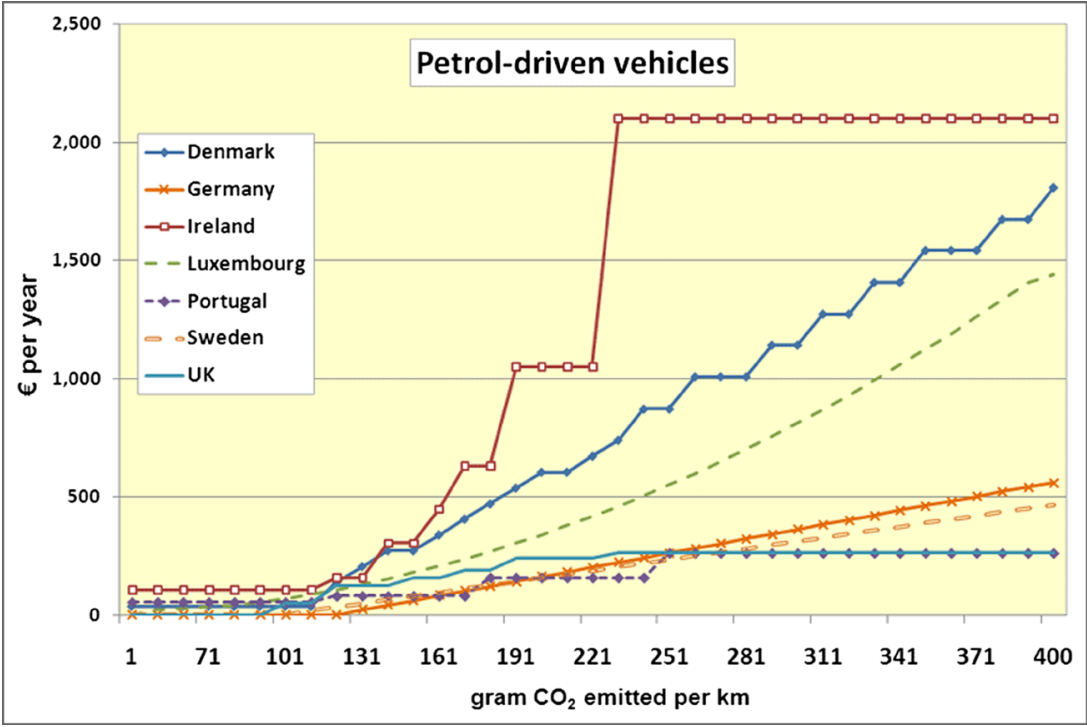

[74]. Purchase or registration taxes are highly visible, which is very helpful in steering buyers' decisions towards more efficient vehicles and may also result in lower car ownership rates: a $10 \%$ increase in car registration taxes would reduce car ownership in European cities by about $1.4 \%$ [74], which would, in turn, result in lower overall car use and a higher share of more efficient modes in urban areas. However, there may be negative welfare or equity implications [27]. Taxes imposed at the time of the first registration may also delay the renewal of the vehicle fleet, as car owners may keep their vehicles longer and may prefer to replace current vehicle with other used rather than new ones. An ex-post assessment of the Netherland's feebates estimated the scheme saved approximately $0.6-1 \mathrm{~m}$ tonnes of $\mathrm{CO}_{2}$ per annum [28], approximately $2-3 \%$ of the Netherland's total transport sector $\mathrm{CO}_{2}$ emissions. The Dutch system's provision of direct incentives to buy very efficient cars has had a measurable effect on purchasing decisions, with the market share of cars from the highest efficiency class increasing from 0.3 to $3.2 \%$, and that for the second highest class increasing from 9.5 to $16.1 \%$ in 2002 [90]. Following the government's decision to discontinue the feebates, efficient cars' market share dropped almost instantly, although it stayed higher than before the scheme's introduction [74].

In December 2007, France established a feebate scheme. The scheme provides a rebate of up to $€ 5000$ for vehicles with $\mathrm{CO}_{2}$ emissions below $60 \mathrm{~g} / \mathrm{km}$ (e.g. electric vehicles and plug-in hybrids) and charges fess of up to $€ 2600$ for cars with $\mathrm{CO}_{2}$ emissions above $250 \mathrm{~g} / \mathrm{km}$. According to official figures, the scheme has been very successful, with sales of vehicles with $\mathrm{CO}_{2}$ emissions lower than $130 \mathrm{~g} / \mathrm{km}$ increasing $45 \%$ in the scheme's first 8 months. A number of ex-ante estimates have been made of the policy potential of feebate schemes. A feebate scheme of US\$ 1000 for every 0.01 gallon per mile improvement, if introduced in the United States for 1 year and then ceased, would increase the efficiency of the light vehicle fleet by $24 \%$ over the following 10 to 15 years [26]. Langer (2005) estimated that a feebate of US $\$ 1825 /$ gallon/100mi $(4.25 \mathrm{~L} / \mathrm{km})$ would reduce the average fuel consumption of vehicles entering the fleet $16 \%$ by 2010 and $28 \%$ by 2020 .

\subsection{Local level policies and measures}

\subsubsection{Compact city design and integrated planning}

Compact cities provide the opportunity for shorter travel distances and can avoid unnecessary travel. Higher population densities provides the basis for mass-transportation modes and can enable the integration of public transport and nonmotorised transport infrastructure [30]. Combined with mixed use, these factors can reduce travel distances, and improve accessibility and efficiency of public transport [86]. While the development of urban form and transport infrastructure are long-term processes, there is a large potential that sustainable urban planning can influence cities that are small to medium size and rapidly growing as is the case today in many developing countries [87, 1].

\subsubsection{Public transport, walking and cycling}

Another vital aspect for low-carbon and accessible transport is the provision of high-quality public transport infrastructure and services as well as walking and cycling facilities [73]. Cities that invest considerably in public transport and in walking and cycling infrastructure tend to achieve higher 
Fig. 4 Per capita transport $\mathrm{CO} 2$ emissions 1991-2010 of selected countries. Source: IEA World Energy Database 2013

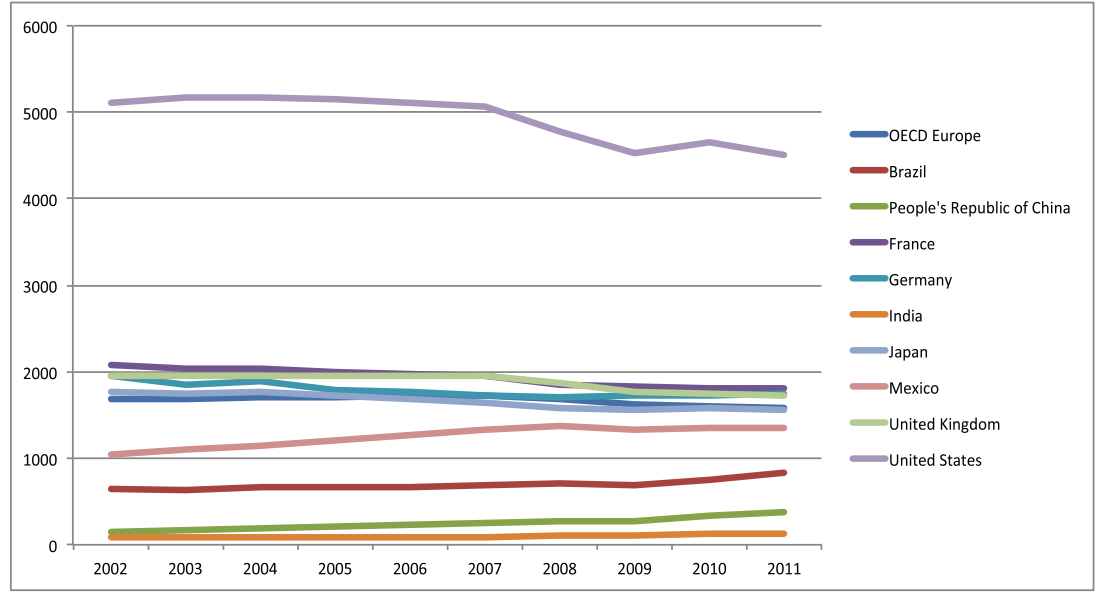

shares of these modes, which increases the economic efficiency of transport and reduces public health and environmental impacts as well as congestion [86].

Metro system (MRT), Lightrail (LRT) and Bus Rapid Transit (BRT), provide options for high capacity and high average speed mass transit options, which can provide highly cost-effective alternatives to individual motirised transport, at least over the long-term. Fulton et al. [19] suggests that doubling the market share of public transport, walking and cycling could yield cumulative savings of over US\$100 trillion over a 40 year period.

Walking any cycling infrastrcuture along with measures such as bikesharing schemes and bike parking facilities provide modal alternatives and also act as feeder to the public transport system. Long-term master plans for the promotion of walking cycling and public transport, such as those developed by the cities of Freiburg (Germany) and Odense (Denmark) that led to an increase of cycling in the modal share to $26 \%$ (1999 Freiburg) and $35 \%$ (2001 Odense) [18].

\subsubsection{Urban logistics}

Urban freight transport creates a disproportionate level of negative impacts, such as greenhouse gas and harmful emissions, noise and congestion. For some time now, authorities at the national and local level in Europe have tried to address this challenge and manage freight in urban areas more effectively to foster sustainable development in cities. Key freight policies include logistics, supply china management. By integrating transport modes, warehousing and inventory, logistics enables more efficient and seamless flows of goods in a globalised economy. Integrated supply chain management concepts can optimise vehicle utilization, energy efficiency and modal choice [53]. Just-in-time delivery reduces the need for warehousing and increases supply chain efficiencies, but also increases the need for packaging hence increasing volume rather than weight, which limits load factor [43].

\section{Policy packaging to overcome the barriers}

It is often claimed that transport is the hardest sector to decarbonise [15, 34]. However, some countries have managed to curb emissions in this sector, at least to some extent. While it is acknowledged that current measures in most, if not all, countries will not be sufficient to bring transport onto a $2{ }^{\circ} \mathrm{C}$ pathway, some countries have shown reasonable progress (Fig. 4).

France, Japan, the United Kingdom and Germany are among the few developed countries that have seen a policyled decline in transport GHG emissions in recent years. These

Table 2 Elements of a multi-modal, multi-level sustainable transport package

\begin{tabular}{ll}
\hline Examples for national measures & Examples for local measures \\
\hline Fuel tax & Compact city design and integrated planning \\
Vehicle tax based on fuel efficiency and/or CO2 emissions & Provision of public transport, walking and cycling infrastructure and services \\
Vehicle fuel efficiency regulation and labelling & Urban logistics \\
& Travel demand management, incl. Road User Charging, parking pricing, access restrictions \\
& Registration restrictions and number plate auctions \\
& Public awareness campaigns, eco-driving schemes \\
\hline
\end{tabular}


countries stand out as they have seen their road greenhouse gas emissions stabilise or even decrease, despite economic and road-freight growth over the same period [38]. What these countries have in common is that they all have the policies in place mentioned above and not just one of them (e.g. vehicles standards in the US), but all of them. In addition to that many cities in France, the UK, Germany and Japan have a compact design and provide modal choices [71]. The US shows substantial improvements over the last years, but from a much higher level. Standards certainly made a contribution to this, but also the saturation of travel demand is reflected by this. It is doubtful if levels similar to France or Japan can be achieved with a policy approach largely based on one measure. The emerging economies of India, China Brazil and Mexico show a clear upward trend, which can only be managed if the policies outlined in this paper are implemented on the national level and complemented with city planning and local policies.

A number of studies emphasize that vehicle fuel efficiency improvements are a key measure to cost-effectively reduce transport-sector energy consumption (and thus greenhouse gas emissions), in particular over the short- and medium term [71]. While emissions reductions can be achieved through several means, such as modal shift, efficiency gains and reduced transport activity, it is apparent that vehicle efficiency has a key role to play. Fulton et al. [19] state that significant cuts in overall travel and substantial modal shifts would be needed to make up for slightly reduced fuel efficiency improvement in OECD countries, and similarly, that travel demand growth would need to be curbed significantly if reasonable efficiency gains are not continued in developing countries. While in developing and emerging countries will be more on maintaining the currently still high share of lowcarbon transport modes, fuel efficiency will play an important role to facilitate the growth in travel demand and still making a contribution to global climate change mitigation efforts. Vital element for this strategy is a policy package as outlined in the previous sections and summarised in the table below (Table 2).

While this paper focuses on the ability of an integrated policy approach to overcome barriers, it is acknowledged that not only the policies themselves (content) are an important element in this equation, but also the policy environment (context) [42]. This context includes not only socio-economic, but also political aspects, taking into account the institutional structures of countries. The combination of policies and policy objectives can help building coalitions, but can also increase the risk of the failure of the package if one measure faces strong opposition, which, however, can be overcome if the process in managed carefully [75]. A vital element of success is the involvement at an early stage of potential veto players and the incorporation of their policy objectives in the agenda setting [85].

\section{Conclusion}

Reducing greenhouse gas emissions in the transport sector is a significant challenge. Progress in this area is very disparate from country to country, but it is apparent, as explored in this paper, that policies are the vital element that can explain these differences. Policy packaging and integration is a vital element of the (relative) successes. Policies have to be designed to be part of a consistent framework, with the aim of improving vehicle fleet efficiency, encouraging efficient vehicle use, enouraging shifts and low-carbon transport modes and reduce the overall travel demand. If applied in isolation these measures are unlikely to achieve their stated goals of reducing overall emissions and increasing transport sector energy efficiency. For example, vehicle standards alone are likely to increase the fleet's efficiency, but this improvement is likely to be offset by increased vehicle use (rebound effect). Similarly, increased fuel taxes, without the provision of modal alternatives and/or measures to ensure a supply of efficient vehicles, would impact negatively on mobility and transport affordability. Hence a balanced and integrated policy approach is needed that combines vehicle efficiency standards, fuel tax, differentiated vehicle taxes with the provision of modal choices and compact city design.

While the combination of measures is vital to the success of sustainable transport policies, the policy environment and the institutional structures are equally vital to make these policies a success. More research is needed to assess the ability of cobenefit strategies to create the basis for coalitions that can link local and national governments and other relevant veto players.

Acknowledgments Research for this paper has been carried out under the SOLUTIONS project, funded from the European Union's Sevens Framework Programme for research, technological development and demonstration under the grant agreement 604714.

Open Access This article is distributed under the terms of the Creative Commons Attribution License which permits any use, distribution, and reproduction in any medium, provided the original author(s) and the source are credited.

\section{References}

1. Amekudzi AA, Ramaswami A, Chan E, Kin-che L, Zhu D, Meng WH (2011) Contextualizing carbon reduction initiatives: how should carbon mitigation be addressed by various cities worldwide? Carbon Manag 2(4):363-365. doi:10.4155/cmt.11.40

2. Atabani AE, Badruddin IA, Mekhilef S, Silitonga AS (2011) A review on global fuel economy standards, labels and technologies in the transportation sector. Renew Sust Energ Rev 15(9):4586-4610. doi:10.1016/j.rser.2011.07.092

3. Banister D (2008) The sustainable mobility paradigm. Transp Policy 15(2):73-80 
4. Banister D (2011) Cities, mobility and climate change. Spec Sec Altern Travel Futur 19(6):1538-1546. doi:10.1016/j.jtrangeo.2011. 03.009

5. Barker T, Rubin JD (2007) Macroeconomic effects of climate policies for road transport: efficiency agreements vs. Fuel Taxation for the United Kingdom, 2000-2010, Transp Res Board 86th Ann Meet

6. Baumol WJ, Oates WE (1988) The theory of environmental policy, 2nd. Cambridge University Press, Cambridge

7. Boschmann EE (2011) Job access, location decision, and the working poor: a qualitative study in the Columbus, Ohio metropolitan area. Geoforum 42(6):671-682. doi:10.1016/j.geoforum.2011.06.005

8. Brookes L (2000) Energy efficiency fallacies revisited. Energy Pol 28(6-7):355-366

9. Carisma B, Lowder S (2007) Estimating the economic costs of traffic congestion: a review of literature on various cities \& countries

10. Cherp A, denikinju. A, Goldthau A, Hernandez F, Hughes L, Jaap J, Jewell J et al (2012) Chapter 5 - Energy and security. In Global Energy Assessment - Toward a Sustainable Future, 325-84. Cambridge University Press, Cambridge, UK and New York, NY, USA and the International Institute for Applied Systems Analysis, Laxenburg, Austria. http://www.globalenergyassessment.org

11. Clerides S, Zachariadis $\mathrm{T}$ (2008) The effect of standards and fuel prices on automobile fuel economy: an international analysis. Energy Econ 30(5):2657-2672

12. Creutzig F, Dongquan H (2009) Climate change mitigation and Cobenefits of feasible transport demand policies in beijing. Transp Res Part D: Transp Environ 14(2):120-131. doi:10.1016/j.trd.2008.11. 007

13. Diamond J (2005) How societies choose to fail or succeed. Viking Penguin, New York

14. Dietz T, Ostrom E, Stern PC (2003) The Struggle to Govern the Commons. Science 302:1977-1990

15. ECMT (2007) Cutting transport CO emissions: what progress? Paris: OECD. http://www.internationaltransportforum.org/Pub/pdf/ 07CuttingCO2.pdf

16. Hartog D, Johan J, Boogaard H, Nijland H, Hoek G (2010) Do the health benefits of cycling outweigh the risks? Environ Health Perspect 118(8):1109-1116. doi:10.1289/ehp.0901747

17. DfT UK. (2009) Impact assessment of the carbon reduction strategy for transport ECMT. 2007. Cutting transport CO2 emissions: what progress?. Paris: OECD. http://www.internationaltransportforum. org/Pub/pdf/07CuttingCO2.pdf

18. Figueroa M, Lah O, Fulton LM, McKinnon A, Tiwari G (2014) Energy for transport. Ann Rev Environ Resour 39(1):295-325. doi: 10.1146/annurev-environ-031913-100450

19. Fulton L, Lah O, Cuenot F (2013) Transport pathways for light duty vehicles: towards a $2^{\circ}$ scenario. Sustainability 5(5):1863-1874. doi: $10.3390 /$ su 5051863

20. GEA (2012) Global energy assessment - toward a sustainable future. Cambridge University Press, Cambridge, UK and New York, NY, USA and the International institute for applied systems analysis, laxenburg, Austria. www.globalenergyassessment.org

21. Giblin S, McNabola A (2009) Modelling the impacts of a carbon emission-differentiated vehicle tax system on $\mathrm{CO} 2$ emissions intensity from new vehicle purchases in Ireland. Energy Pol 37(4):1404-1411

22. Gillingham K, Kotchen MJ, Rapson DS, Wagner G (2013) Energy policy: the rebound effect is overplayed. Nature 493(7433):475-476. doi:10.1038/493475a

23. Givoni M (2014) Addressing transport policy challenges through policy-packaging. Policy Packag 60:1-8. doi:10.1016/j.tra.2013.10.012

24. Goodwin P (2004) The economic costs of road traffic congestion. UCL (University College London), The Rail Freight Group, London

25. Greene DL (2009) Feebates, footprints and highway safety. Transp Res Part D: Transp Environ 14(6):375-384
26. Greene DL, Patterson PD, Singh M, Li J (2005) Feebates, rebates and gas-guzzler taxes: a study of incentives for increased fuel economy. Energy Pol 33(6):757-775

27. Gross R, Heptonstall P, Anable J, Greenacre P; E4tech (2009) What policies are most effective at reducing carbon emissions from transport? A comparison of interventions to encourage behavioural change and technological improvements. UKERC Report

28. Harmsen R, Kroon P, Ybema JR, Jespersen MS, Jordal-Jørgensen J (2003) International CO2 Policy Benchmark For The Road Transport Sector - Results of a pilot study, ECN, ECN-C-03-001

29. Hultkrantz L, Lindberg G, Andersson C (2006) The value of improved road safety. J Risk Uncertain 32(2):151-170

30. Hymel KM, Small KA, Dender KV (2010) Induced demand and rebound effects in road transport. Transp Res B Methodol 44(10): $1220-1241$

31. ICCT (2013) Global passenger vehicle standards. Int Counc Clean Transp. Available at: http://www.theicct.org/info-tools/globalpassen-ger-vehicle-standards

32. IEA (1998) The rebound effect: a review of U.S. literature Organisation for Economics Cooperation and Development: International Energy Agency, Paris

33. IEA (2009) Transport, energy and CO2: moving toward sustainability. International Energy Agency, Paris

34. IEA (2011) World energy outlook 2011. International Energy Agency, OECD/IEA, Paris

35. IEA (2012) Energy technology perspectives 2012. International Energy Agency, Paris

36. IEA (2013) Redrawing the energy climate map. world energy outlook special report. International Energy Agency, Paris

37. Inhaber H (1997) Why energy conservation fails. Westport, Conn., Quorum Books

38. International Transport Forum (ITF) (2009) Reducing transport GHG emissions: opportunities and costs. preliminary findings, Paris: OECD

39. Jacobsen PL (2003) Safety in numbers: more walkers and bicyclists, safer walking and bicycling. Inj Preven 9(3):205-209

40. Jewell J, Cherp A, Riahi K (2013) Energy security under decarbonization energy scenarios. Energy Pol 65:743-760

41. JICA (2005) The master plan for Lima and Callo metropolitan area urban transportation in the republic of Peru; chapter 6, traffic control and management conditions. transport council of Lima and Callo, ministry of transportation and communications of the republic of Peru

42. Justen A, Schippl J, Lenz B, Fleischer T (2014) Assessment of policies and detection of unintended effects: guiding principles for the consideration of methods and tools in policy-packaging. Policy Packag 60:19-30. doi:10.1016/j.tra.2013.10.015

43. Kamakaté F, Schipper L (2009) Trends in truck freight energy use and car- bon emissions in selected OECD countries from 1973 to 2005. Energy Pol 37:3743-3751. doi:10.1016/j.enpol. 2009.07.029

44. Khazzoom JD (1987) Energy savings resulting from the adoption of more efficient appliances. Energy J 1(4):21-40

45. Kunieda M, Gauthier. A, (2007) Gender and urban transport: smart and affordable - module 7a. sustainable transport: A sourcebook for policy-makers in developing cities. Eschborn, Germany: Deutsche Gesellschaft fur Technische Zusammenarbeit (GTZ).

46. Leiby PN (2007) Estimating the energy security benefits of reduced U. S. oil imports, estimating the energy security benefits of reduced US oil imports.

47. Leinert S, Daly H, Hyde B, Ó Gallachóir B (2013) Co-benefits? not always: quantifying the negative effect of a CO2-reducing Car taxation policy on NOx emissions. Energy Policy 63(December):11511159. doi:10.1016/j.enpol.2013.09.063 
48. Lescaroux F (2010) Car ownership in relation to income distribution and consumers' spending decisions. J Transp Econ Policy (JTEP) 44(2):207-230

49. Leung GCK (2011) China's energy security: perception and reality. Energy Pol 42(3):1330-1337. doi:10.1016/j.enpol.2010.12.005

50. Marshall JD (2011) Energy-efficient urban form. Environ Sci Technol 42(9):3133-3137. doi:10.1021/es0870471

51. Litman T (2008) Transportation elasticities: how prices and other factors affect travel behavior. Victoria Transport Policy Institute, Victoria

52. McKinsey, and Company. (2009) Roads toward a low-carbon future: reducing $\mathrm{CO} 2$ emissions from passenger vehicles in the global road transportation system.

53. McKinnon A, (2010) Green Logistics: the Carbon Agenda. Electronic Scientific Journal of Logistics 6, 1-9. Available at: http://www.logforum.net/pdf/6_3_1_10Pdf

54. de Miranda HF, Rodrigues da Silva AN (2012) Benchmarking sustainable urban mobility: the case of Curitiba, Brazil. Transp Policy 21:141-151

55. National Highway Traffic Safety Administration (NHTSA) (2008) Average fuel economy standards: Passenger cars and light trucks model years 2011-2015. US Dep Transport

56. Nemry F et al (2009) Feebate and scrappage policy instruments. Luxemb Off Off Publ Eur Communities 2009

57. Olson M (1965) The logic of collective action; public goods and the theory of groups, harvard economic studies. Harvard University Press, Cambridge

58. Plotkin SE, Singh MK, Ornl (2009) Multi-Path Transportation Futures Study: Vehicle Characterization and Scenario Analyses. Available at: http://www.osti.gov/servlets/purl/968962-2I2Sit/

59. de Rabl A, Nazelle A (2012) Benefits of shift from car to active transport. Transp Policy 19(1):121-131. doi:10.1016/j.tranpol.2011. 09.008

60. Rojas-Rueda D, de Nazelle A, Tainio M, Nieuwenhuijsen MJ (2011) The health risks and benefits of cycling in urban environments compared with car use: health impact assessment study. Br Med J 343:1-8

61. Ruzzenenti F, Basosi R (2008) The rebound effect: an evolutionary perspective. Ecol Econ 67(4):526-537. doi:10.1016/j.ecolecon.2008. 08.001

62. Ryan L, Ferreira S, Convery F (2009) The impact of fiscal and other measures on new passenger car sales and $\mathrm{CO} 2$ emissions intensity: Evidence from Europe. Energy Econ 31(3):365-374

63. Santos G, Behrendt H, Teytelboym A (2010) Part II: policy instruments for sustainable road transport. Res Transp Econ 28(1):46-91. doi:10.1016/j.retrec.2010.03.002

64. Schipper L (2007) Vehicle efficiency and CO2 emissions: troubling trends. EMBARQ - WRI Center for Sustainable Transport, Washington DC

65. Schipper L (2008) "Automobile fuel; economy and CO2 emissions in industrialized countries: troubling trends through 2005/6." 87th annual meeting of the transportation research board.

66. Shakya SR, Shrestha RM (2011) Transport sector electrification in a hydropower resource rich developing country: energy security, environmental and climate change Co-benefits. Energy Sust Deve 15(2): 147-159. doi:10.1016/j.esd.2011.04.003

67. Shalizi Z, Franck L, (2009) Climate change and the economics of targeted mitigation in sectors with long-lived capital stock. 5063. world bank policy research working paper. Washington DC, USA: World Bank. http://ssrn.com/paper=1478816

68. Sharpe R, (2010) Technical GHG Reduction Options for Fossil Fuel Based Road Transport. European Commission Directorate-General Environment, Brussels, Belgium, 50 pp. Available at: http://www. eutransportghg2050.eu/cms/assets/Paper-1-preliminary.pdf

69. Sharpe B, (2011) EPA/NHTSA Greenhouse gas emissions and fuel efficiency standards for medium- and heavy-duty engines and
Vehicles. Int Council Clean Transp. http://www.theicct.org/2011/01/ us-proposed-hdv-standards

70. Sietchiping R, Permezel MJ, Ngomsi C (2012) Transport and mobility in Sub-Saharan African cities: an overview of practices, lessons and options for improvements. special section: Urban Planning in Africa (pp. 155-191). 29(3):183-89. doi:10.1016/j.cities.2011.11.005

71. Sims RR, Schaeffer F, Creutzig X, Cruz-Núñez M, D’Agosto D, Dimitriu MJ, Figueroa Meza L, Fulton S, Kobayashi O, Lah A, McKinnon P, Newman M, Ouyang JJ, Schauer D, Sperling Tiwari G, (2014) Transport. In: Climate Change 2014: Mitigation of Climate Change. Contribution of Working Group III to the Fifth Assessment Report of the Intergovernmental Panel on Climate Change [Edenhofer, O., R. Pichs-Madruga, Y. Sokona, E. Farahani, S. Kadner, K. Seyboth, A. Adler, I. Baum, S. Brunner, P. Eickemeier, B. Kriemann, J. Savolainen, S. Schlömer, C. von Stechow, T. Zwickel and J.C. Minx (eds.)]. Cambridge University Press, Cambridge, United Kingdom and New York, NY, USA.

72. Skinner I, van Essen H, Smokers R, Hill N (2010) Towards the decarbonisation of EU's transport sector by 2050 Final report produced under the contract ENV.C.3/SER/2008/0053 between European Commission Directorate-General Environment and AEA Technology plc; see http://www.eutransportghg2050.eu

73. Small KA, Verhoef ET (2007) The economics of urban transportation. Routledge, New York

74. Smokers R, Vermeulen R, van Mieghem R, Gense R, Skinner I, Fergusson M, Mackay E, ten Brink P, Fontaras, G, Samaras Z (2006) Review and analysis of the reduction potential and costs of technological and other measures to reduce CO2- emissions from passenger cars.

75. Sørensen $\mathrm{CH}$, Isaksson $\mathrm{K}$, Macmillen J, Åkerman J, Kressler F (2014) Strategies to manage barriers in policy formation and implementation of road pricing packages. Policy Packag 60:40-52. doi:10. 1016/j.tra.2013.10.013

76. Sorrell S (2009) Jevons' paradox revisited: the evidence for backfire from improved energy efficiency. Energy Pol 37(4): 1456-1469

77. Sorrell S (2010) Energy, economic growth and environmental sustainability: five propositions. Sustainability 2(6):1784-1809

78. Sorrell St, Speirs J, (2009) UKERC Review of Evidence on Global Oil Depletion - Technical Report 1: Data Sources and Issues. UKERC/WP/TPA/2009/016. Sussex/ London, UK: UK Energy Research Centre.

79. Sovacool B, Marilyn K, Brown A, (2010) Competing dimensions of energy security: an international perspective. In Ann Revf Environ Res Vol 35, edited by A. Gadgil and D. M. Liverman, 35:77-108. Palo Alto, USA: Annual Reviews

80. Stern N (2006) Stern review on the economics of climate change

81. Stern PC, Dietz T, Dolsak N, Ostrom E, Stonich S, in The Drama of the Commons, Ostrom E, (Ed.) (2002) Washington, DC: National Academy Press, pp. 445-490

82. TFL (2007) Transport for London annual report and statement of accounts. London, UK: transport for London. http://www.tfl.gov.uk/ assets/downloads/annual-report-and-statement-of-accounts-06-07. pdf

83. TIS (2002) Study on Vehicle Taxation in the Member States of the European Union, Conducted for: European Commission - DG Taxation and Customs Union, Consultores em Transportes Inovacao e Sistemas, S.A

84. Tiwari G, Jain D (2012) Accessibility and safety indicators for All road users: case study Delhi BRT. J Transp Geogr 22:87-95. doi:10. 1016/j.jtrangeo.2011.11.020

85. Tsebelis G, Garrett G (1996) Agenda setting power, power indices, and decisionmaking in the european union. Int Rev Law Econ 16(3): 345-361. doi:10.1016/0144-8188(96)00021-X 
86. UN-Habitat. (2013) Planning and design for sustainable urban mobility - global report on human settlements 2013. Nairobi, Kenya: UN-HABITAT. http://www.unhabitat.org/content.asp?catid= 555\&typeid $=19 \&$ cid $=12336$

87. United Nations. (2010) State of the world's cities 2010/2011: Bridging the Urban Divide. United Nations Human Settlements Programme. London; Washington, DC: Earthscan

88. Van Dender K (2009) Energy policy in transport and transport policy. Energy Pol 37(10):3854-3862
89. Viguié V, Hallegatte S (2012) Trade-offs and synergies in urban climate policies. Nat Clim Chang 2(5):334-337. doi: $10.1038 /$ nclimate 1434

90. VROM (2003) Evaluatie studie Energiepremie, Netherlands Ministry of Housing, Spatial Planning and the Environment

91. World Bank (2002) Cities on themove : a world bank urban transport strategy review. The World Bank, Washington

92. World Energy Council (WEC) (2008) Assessment of energy policies and practices. WEC, London 